\title{
Kinetic Resolution of $\alpha$-Acetoxy- $N$-Acyl Oxazolidinethiones by a Chiral O-Nucleophilic Acyl Transfer Catalyst
}

\author{
Gregory T. Notte, Tarek Sammakia, ${ }^{*}$ and Peter J. Steel ${ }^{ \pm}$ \\ Department of Chemistry and Biochemistry, University of Colorado, Boulder, Colorado \\ 80309-0215 and Department of Chemistry, College of Science, University of Canterbury, \\ Christchurch, New Zealand \\ Supporting Information
}

Table of Contents:

S1-S2 General Information

S2-S3 Synthesis and characterization of catalyst 8.

S3-S5 Synthesis and characterization of compounds $\mathbf{1 0}$ to 15.

S6 Typical kinetic resolution procedure.

S6-S8 Kinetic resolution of compounds $\mathbf{1 0}$ to $\mathbf{1 5 .}$

S8-S9 Determination of absolute configuration.

S9-S10 X-ray structure of compound 8

S11-S26 ${ }^{1} \mathrm{H}$ and ${ }^{13} \mathrm{C}$ NMR spectra for compounds 7, 8, and 10 - 15 (separate PDF file).

General Information. All air or moisture sensitive reactions were conducted in oven dried glassware under a dry nitrogen atmosphere. Methylene chloride, reagent grade hexane, methanol, and Hunig's base, were distilled from $\mathrm{CaH}_{2}$. Toluene was washed with concentrated $\mathrm{H}_{2} \mathrm{SO}_{4}, \mathrm{H}_{2} \mathrm{O}, 1 \mathrm{M} \mathrm{NaOH}$, and $\mathrm{H}_{2} \mathrm{O}$, dried over $\mathrm{MgSO}_{4}$, then filtered and distilled from $\mathrm{CaH}_{2}$. THF was distilled from $\mathrm{Na}$ benzophenone ketyl under nitrogen. 3-phenyllactic acid was purchased from Lancaster and used as received; mandelic acid, 2-hydroxycaproic acid, and 2-hydroxy-3-methylbutyric acid were purchased from Aldrich and used as received. 1,3-Oxazolidine-2-thione was synthesized in $90 \%$ yield from ethanolamine and carbon disulfuide by the procedure of $\mathrm{Li}^{1}{ }^{1}(S)-(-)-$ $N, N$-Dimethyl-1-phenethylamine can be purchased from Aldrich or synthesized in $65 \%$ yield from (S)-(-)-phenethylamine following the procedure of Ollis. ${ }^{2}$ Flash chromatography of substrates $10(\mathrm{R}=$ phenyl) and $15(\mathrm{R}=$ allyl $)$ was performed on neutral silica gel (Mallinckrodt Silicar Silica Gel 150, 60-200 mesh (75-250 micron))

\footnotetext{
$\pm \quad$ University of Canterbury

1 Li, G. Ohtani, T. Heterocylcles 1997, 45, 2471. 7.

2 Ollis, W.; Rey, M.; Sutherland, I. J. Chem Soc. Perk. Trans. 1. 1983, 1009. 7.
} 
following the procedure of Still. ${ }^{3}$ Flash chromatography of these substrates on other "ordinary" silica gel (i.e. silica gel with a $\mathrm{pH}$ other than 7.0) led to partial cleavage of the oxazolidinethione auxiliary. All other flash chromatography was performed using Sorbent Technologies $60 \AA$ silica gel (32-63 micron). ${ }^{1} \mathrm{H}$ NMR spectra were recorded at $500 \mathrm{MHz}$ or $400 \mathrm{MHz}$ in $\mathrm{CDCl}_{3}$ and were referenced to residual $\mathrm{CHCl}_{3}(7.24 \mathrm{ppm}) .{ }^{13} \mathrm{C}$ NMR spectra were obtained at $100 \mathrm{MHz}$ in $\mathrm{CDCl}_{3}$ and were referenced to the center line of the $\mathrm{CDCl}_{3}$ triplet $(77.23 \mathrm{ppm})$. Chiral HPLC analysis was performed using a semipreparative Chiralcel OD column $(250$ x $4.6 \mathrm{~mm})$. Compounds were detected by monitoring UV absorbance at $254 \mathrm{~nm}$. Infrared spectra were recorded as thin films on $\mathrm{NaCl}$ plates. Melting points were determined in capillaries and are uncorrected. Optical rotations were determined on a JASCO 1030 polarimeter at $27{ }^{\circ} \mathrm{C}$. Combustion analyses were performed by NuMega Resonance Labs, Inc. of San Diego, CA. Exact mass was determined on $\mathrm{M}+\mathrm{Na}$ using electrospray ionization.

\section{Catalyst Synthesis}

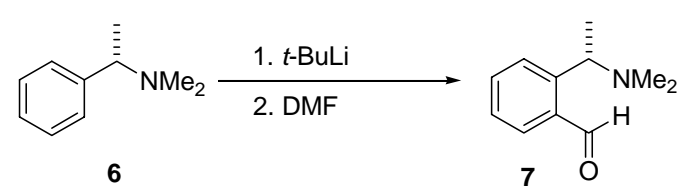

Amine 6 (110.0 mg, .737 mmol) was dissolved in hexane $(5 \mathrm{ml})$ and cooled to 0 ${ }^{\circ} \mathrm{C}$. t-Butyl lithium $(473 \mu \mathrm{L}, 1.59 \mathrm{M}, .752 \mathrm{mmol})$ was added dropwise and the reaction was stirred for $15 \mathrm{~min}$ at $0{ }^{\circ} \mathrm{C}$. The reaction was warmed to room temperature and stirred for $20 \mathrm{~h}$, then cooled to $0{ }^{\circ} \mathrm{C}$, and DMF $(85.6 \mu \mathrm{L}, 1.1 \mathrm{mmol})$ was added. After $15 \mathrm{~min}$, the reaction was quenched by the addition of $3 \mathrm{M} \mathrm{NaOH}$. The aqueous layer was extracted with $\mathrm{Et}_{2} \mathrm{O}\left(4 \times 10 \mathrm{ml}\right.$ ), and the combined organics were dried over $\mathrm{MgSO}_{4}$, filtered and concentrated at reduced pressure to a yellow oil. Purification by flash chromatography $\left(3: 1 \mathrm{EtOAc}-\mathrm{MeOH}\right.$ with $\left.10 \% \mathrm{Et}_{3} \mathrm{~N}\right)$ provided aldehyde 7 (109 $\left.\mathrm{mg}, 84 \%\right)$ as a clear oil.

${ }^{1} \mathrm{H}$ NMR (400 MHz, $\left.\mathrm{CDCl}_{3}\right): \delta 10.32(\mathrm{~s}, 1 \mathrm{H}), 7.74(\mathrm{~m}, 1 \mathrm{H}), 7.42-7.49(\mathrm{~m}, 2 \mathrm{H})$, 7.33-7.37 (m, 1H), $4.03(\mathrm{q}, 1 \mathrm{H}, \mathrm{J}=6.4 \mathrm{~Hz}), 2.18(\mathrm{~s}, 1 \mathrm{H}), 1.38(\mathrm{~d}, 3 \mathrm{H} \mathrm{J}=6.4 \mathrm{~Hz}) .{ }^{13} \mathrm{C}$ NMR $\left(100 \mathrm{MHz}, \mathrm{CDCl}_{3}\right): \delta 189.9,147.1,135.4,133.0,129.4,127.4,127.3,61.0,42.1,16.9$. IR $\left(\mathrm{cm}^{-1}\right) 2976,1690 .[\alpha]_{\mathrm{D}}=-71.5(\mathrm{c}=2.41, \mathrm{EtOAc})$.
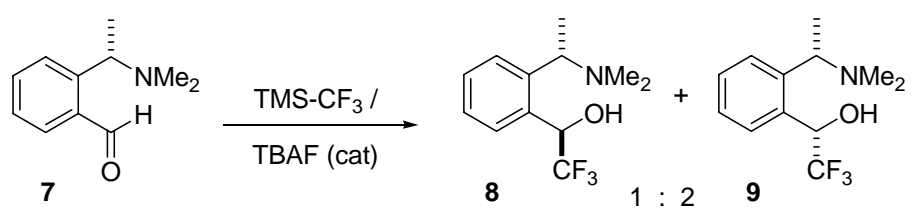

Aldehyde 7 (438 mg, $2.48 \mathrm{mmol})$ was dissolved in THF (25 ml) and cooled to 0 ${ }^{\circ} \mathrm{C}$. $\mathrm{TMS}^{-\mathrm{CF}_{3}}$ (5.94 $\mathrm{ml}$ of a $0.5 \mathrm{M}$ solution in THF, $\left.2.97 \mathrm{mmol}\right)$ was slowly added to the 
reaction. After stirring for $5 \mathrm{~min}$, tetrabutylammonium fluoride hydrate $(25 \mathrm{mg}, 0.095$ mmol) in THF (1 ml) was added, and the reaction was warmed to room temperature and stirred for $4 \mathrm{~h}$. The reaction was quenched and the TMS ether was hydrolyzed by the addition of $\mathrm{HCl}(5 \mathrm{ml}$ of a $1 \mathrm{M}$ solution, $5 \mathrm{mmol})$. The reaction was stirred for $1 \mathrm{~h}$, then diluted with EtOAc, and washed with saturated aqueous $\mathrm{K}_{2} \mathrm{CO}_{3}(2 \times 20 \mathrm{ml})$. The organic layer was dried over $\mathrm{MgSO}_{4}$, filtered, and concentrated at reduced pressure to a yellow oil consisting of a 1:2 mixture of $\mathbf{8}$ and 9. Separation of these diastereomeres was accomplished by flash chromatography $\left(35: 1\right.$ hexanes- $\left.\mathrm{Et}_{3} \mathrm{~N}\right)$ to provide the diastereomerically pure trifluoromethyl alcohols 8 (minor diastereomer, faster eluting, $188 \mathrm{mg}, 31 \%$ ) and 9 (major diastereomer, slower eluting, $369 \mathrm{mg}, 61 \%$ ). Other solvent systems examined did not provide complete separation of these isomers.

${ }^{1} \mathrm{H}$ NMR $\left(500 \mathrm{MHz}, \mathrm{CDCl}_{3}\right): \delta 11.22(\mathrm{~s}, 1 \mathrm{H}), 7.29-7.41(\mathrm{~m}, 4 \mathrm{H}), 5.07(\mathrm{q}, 1 \mathrm{H}$, $\mathrm{J}=8.5 \mathrm{~Hz}), 4.52(\mathrm{q}, 1 \mathrm{H}, \mathrm{J}=7 \mathrm{~Hz}), 2.23(\mathrm{~s}, 6 \mathrm{H}), 1.43(\mathrm{~d}, 3 \mathrm{H}, \mathrm{J}=7 \mathrm{~Hz}) .{ }^{13} \mathrm{C}$ NMR $(100 \mathrm{MHz}$, $\left.\mathrm{CDCl}_{3}\right): \delta 141.24,135.26,132.53,128.99,128.29,127.89,125.93$ (q, J=283 Hz), 77.21 $(\mathrm{q}, \mathrm{J}=31 \mathrm{~Hz}), 58.81,39.05,8.54 . \mathrm{mp}=57-58 . \quad \mathrm{IR}\left(\mathrm{cm}^{-1}\right) 2983,2954 .[\alpha]_{\mathrm{D}}=-25.5(\mathrm{c}=$ 1.43, EtOAc). Anal. calcd for $\mathrm{C}_{12} \mathrm{H}_{16} \mathrm{~F}_{3} \mathrm{NO}$ : C, 58.29; H, 6.52; N, 5.66; Found: C, 57.89; H, 6.34; N, 5.66.

\section{Synthesis of Substrates:}

\section{General Procedures for Preparation from $\alpha$-Hydroxy Acids}

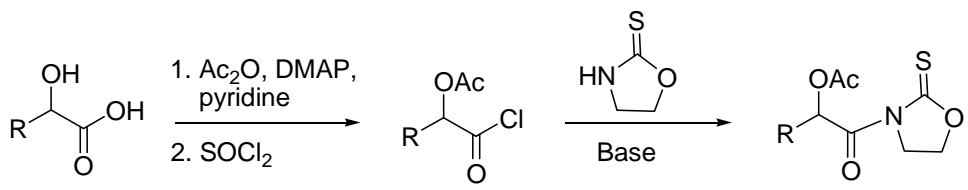

Method A: To a stirred solution of the $\alpha$-hydroxy acid (1.0 mmol) and DMAP $(0.05 \mathrm{mmol})$ in $\mathrm{Et}_{2} \mathrm{O}(3.3 \mathrm{ml}, 0.3 \mathrm{M})$ at $0{ }^{\circ} \mathrm{C}$ was added pyridine $(380 \mu \mathrm{L} / \mathrm{mmol})$. Acetic anhydride $(1.1 \mathrm{mmol})$ was then added to this suspension, and the reaction was stirred for $15 \mathrm{~min}$ at $0{ }^{\circ} \mathrm{C}$, then warmed to room temperature. After $45 \mathrm{~min}$ at room temperature, the reaction was quenched by the addition of $2 \mathrm{M} \mathrm{HCl}$ until the aqueous layer was below $\mathrm{pH}$ 2. The aqueous layer was extracted with $\mathrm{Et}_{2} \mathrm{O}$ (three times), and the combined organic extracts were dried over $\mathrm{MgSO}_{4}$, filtered, and concentrated at reduced pressure to a clear oil. This material sometimes contained traces of pyridine, but was of sufficient purity for use in the subsequent reactions.

To a stirred solution of the crude $\alpha$-acetoxy acid prepared above $(1.0 \mathrm{mmol})$ in $\mathrm{CH}_{2} \mathrm{Cl}_{2}(5 \mathrm{ml}, 0.2 \mathrm{M})$ at $0{ }^{\circ} \mathrm{C}$ was added $\mathrm{SOCl}_{2}(2.0 \mathrm{mmol})$, and the reaction was allowed to stir overnight. The solvent was removed under reduced pressure and the residue dissolved in THF $(7 \mathrm{ml})$ then cooled to $0^{\circ} \mathrm{C}$. 1,3-Oxazolidine-2-thione ${ }^{1}(1.05 \mathrm{mmol}$ in 3 $\mathrm{ml}$ THF) was then added, and the reaction was stirred for 5 min. Hunig's base (1.05 mmol) was then added dropwise over $15 \mathrm{~min}$, and the reaction was stirred at $0{ }^{\circ} \mathrm{C}$ for 15 min, then warmed to room temperature. After $1 \mathrm{~h}$ additional stirring, $\mathrm{H}_{2} \mathrm{O}$ was added to quench the reaction. The reaction was diluted with $\mathrm{Et}_{2} \mathrm{O}$, washed with brine $(2 \mathrm{x})$, dried over $\mathrm{MgSO}_{4}$, filtered, and concentrated at reduced pressure. Purification by flash chromatography (4:1 hexanes-ethyl acetate) affords the product as a white solid, unless otherwise noted. 
Method B: A solution of the acid chloride in THF $(5 \mathrm{ml})$ was prepared as described in Method A, then added to a slurry of 1,3-oxazolidine-2-thione (1.0 mmol) and $\mathrm{NaH}(95 \%, 1.7 \mathrm{mmol})$ in THF $(5 \mathrm{ml}$, final concentration of $0.1 \mathrm{M})$ at $0{ }^{\circ} \mathrm{C}$. The reaction was stirred at $0{ }^{\circ} \mathrm{C}$ for $15 \mathrm{~min}$ then warmed to room temperature for $1 \mathrm{~h}$, and quenched by the addition of water. The reaction was diluted with $\mathrm{Et}_{2} \mathrm{O}$, washed with brine (2x), dried over $\mathrm{MgSO}_{4}$, filtered, and concentrated at reduced pressure. Purification by flash chromatography (4:1 hexanes-ethyl acetate) affords the product as a white solid, unless otherwise noted.

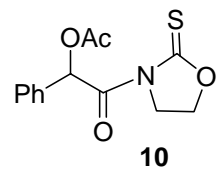

Compound 10 was prepared by method $\mathrm{A}$ in $80 \%$ overall yield.

${ }^{1} \mathrm{H}$ NMR $\left(500 \mathrm{MHz}, \mathrm{CDCl}_{3}\right): \delta 8.02(\mathrm{~s}, 1 \mathrm{H}), 7.55-7.57(\mathrm{~m}, 2 \mathrm{H}), 7.37-7.38(\mathrm{~m}$, $3 \mathrm{H}), 4.55-4.60(\mathrm{~m}, 1 \mathrm{H}), 4.45$ (app q, 1H, J=9 Hz), 4.28-4.34 (m, 1H), 4.11-4.18 (m, 1H), $2.15(\mathrm{~s}, 3 \mathrm{H}) .{ }^{13} \mathrm{C} \mathrm{NMR}\left(100 \mathrm{MHz}, \mathrm{CDCl}_{3}\right): \delta 184.6,171.0,170.1,132.7,129.8,129.7$, 129.0, 73.3, 67.0, 47.5, 20.8. $\mathrm{mp}=139-140{ }^{\circ} \mathrm{C} . \mathrm{IR}\left(\mathrm{cm}^{-1}\right) 1739,1704,1218 . \mathrm{HRMS} \mathrm{m} / \mathrm{z}$ calcd for $\mathrm{C}_{13} \mathrm{H}_{13} \mathrm{NO}_{4} \mathrm{SNa}^{+}$: 302.0457 ; found: 302.0457

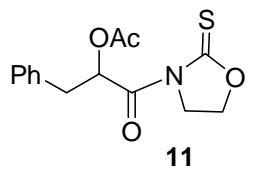

Compound 11 was prepared by method $\mathrm{B}$ in $90 \%$ overall yield.

${ }^{1} \mathrm{H}$ NMR $\left(400 \mathrm{MHz}, \mathrm{CDCl}_{3}\right): \delta 7.26-7.4(\mathrm{~m}, 5 \mathrm{H}), 6.92(\mathrm{X}$ of $\mathrm{ABX}, 1 \mathrm{H}, \mathrm{J}=2.8$, $10.4 \mathrm{~Hz}), 4.56-4.64(\mathrm{~m}, 2 \mathrm{H}), 4.26-4.33(\mathrm{~m}, 1 \mathrm{H}), 4.14-4.21(\mathrm{~m}, 1 \mathrm{H}), 3.46(\mathrm{~A}$ of ABX, 1H, $\mathrm{J}=2.8,14 \mathrm{~Hz}), 3.0(\mathrm{~B}$ of $\mathrm{ABX}, 1 \mathrm{H}, \mathrm{J}=10.4,14 \mathrm{~Hz}), 2.06(\mathrm{~s}, 3 \mathrm{H}) .{ }^{13} \mathrm{C} \mathrm{NMR}(100 \mathrm{MHz}$, $\left.\mathrm{CDCl}_{3}\right): \delta 185.0,171.6,170.9,136.1,129.7,128.6,127.3,73.1,67.3,47.4,36.7,20.7$. $\mathrm{mp}=125-126^{\circ} \mathrm{C}$. IR $\left(\mathrm{cm}^{-1}\right) 1743,1707,1218$. Anal. calcd for $\mathrm{C}_{14} \mathrm{H}_{15} \mathrm{NO}_{4} \mathrm{~S}: \mathrm{C}, 57.32$; H, 5.15; N, 4.77; Found: C, 56.92; H, 5.03; N, 4.78.

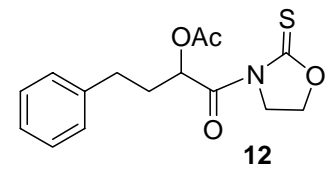

Compound 12 was prepared by method B in 92\% overall yield from the corresponding $\alpha$-acetoxy acid, which was prepared by the method of Weinreb. ${ }^{4}$

${ }^{1} \mathrm{H}$ NMR $\left(500 \mathrm{MHz}, \mathrm{CDCl}_{3}\right): \delta 7.21-7.33,(\mathrm{~m}, 5 \mathrm{H}), 6.71(\mathrm{dd}, 1 \mathrm{H}, \mathrm{J}=2.5,9.5 \mathrm{~Hz})$, 4.53-4.65 (m, 2H), 4.25-4.31 (m, 1H), 4.07-4.13 (m, 1H), 2.87-2.91 (m, 2H), 2.39-2.43 
$(\mathrm{m}, 1 \mathrm{H}), 2.19(\mathrm{~s}, 3 \mathrm{H}), 2.13-2.20(\mathrm{~m}, 1 \mathrm{H}) .{ }^{13} \mathrm{C}$ NMR $\left(100 \mathrm{MHz}, \mathrm{CDCl}_{3}\right): \delta 185.0,171.5$, $171.0,140.9,128.7,128.6,126.4,72.5,67.2,47.3,32.7,31.9,20.7 . \mathrm{mp}=124 . \quad$ IR $\left(\mathrm{cm}^{-1}\right)$ 1743, 1708, 1217. HRMS m/z calcd for $\mathrm{C}_{15} \mathrm{H}_{17} \mathrm{NO}_{4} \mathrm{SNa}^{+}$: 330.0771 ; found: 330.0764

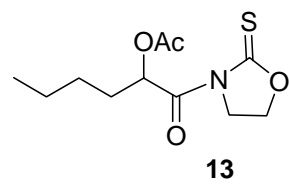

Compound 13 was prepared by method $\mathrm{A}$ in $76 \%$ overall yield as a clear oil.

${ }^{1} \mathrm{H}$ NMR $\left(400 \mathrm{MHz}, \mathrm{CDCl}_{3}\right): \delta 6.6(\mathrm{dd}, 1 \mathrm{H}, \mathrm{J}=2.4,9.6 \mathrm{~Hz}), 4.53-4.63(\mathrm{~m}, 2 \mathrm{H})$, 4.23-4.30 (m, 1H), 4.12- $4.19(\mathrm{~m}, 1 \mathrm{H}), 2.12(\mathrm{~s}, 3 \mathrm{H}), 1.99-2.07(\mathrm{~m}, 1 \mathrm{H}), 1.70-1.80(\mathrm{~m}$, $1 \mathrm{H}), 1.45-1.53(\mathrm{~m}, 2 \mathrm{H}), 1.30-1.39(\mathrm{~m}, 1 \mathrm{H}), 0.901(\mathrm{t}, 3 \mathrm{~h}, \mathrm{~J}=7.2 \mathrm{~Hz}) .{ }^{13} \mathrm{C}$ NMR $(100 \mathrm{MHz}$, $\left.\mathrm{CDCl}_{3}\right): \delta 185.0,172.0,171.0,72.9,67.2,47.3,30.6,27.7,22.5,20.7,14.1$. IR $\left(\mathrm{cm}^{-1}\right)$ 1742, 1709, 1218. Anal. calcd for $\mathrm{C}_{11} \mathrm{H}_{17} \mathrm{NO}_{4} \mathrm{~S}: \mathrm{C}, 50.95 ; \mathrm{H}, 6.61 ; \mathrm{N}, 5.40$; Found: $\mathrm{C}$, $50.66 ; \mathrm{H}, 6.25 ; \mathrm{N}, 5.39$.

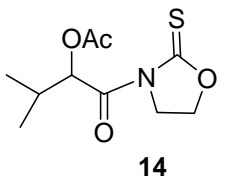

Compound 14 was prepared by method B in $67 \%$ overall yield.

${ }^{1} \mathrm{H}$ NMR $\left(400 \mathrm{MHz}, \mathrm{CDCl}_{3}\right): \delta 6.67(\mathrm{~d}, 1 \mathrm{H}, \mathrm{J}=3 \mathrm{~Hz}), 4.52-4.64(\mathrm{~m}, 2 \mathrm{H}), 4.27-$ $4.34(\mathrm{~m}, 1 \mathrm{H}), 4.13-4.2(\mathrm{~m}, 1 \mathrm{H}), 2.47$ (hd, $1 \mathrm{H}, \mathrm{J}=3,7 \mathrm{~Hz}), 2.14(\mathrm{~s}, 3 \mathrm{H}), 1.1(\mathrm{~d}, 3 \mathrm{H}, \mathrm{J}=7$ $\mathrm{Hz}), 0.96(\mathrm{~d}, 3 \mathrm{H}, \mathrm{J}=7 \mathrm{H}) .{ }^{13} \mathrm{C}$ NMR $\left(100 \mathrm{MHz}, \mathrm{CDCl}_{3}\right): \delta 185.0,171.2,171.1,75.8,67.1$, 47.3, 29.3, 20.7, 19.3, 15.9. $\mathrm{mp}=89-90$. IR $\left(\mathrm{cm}^{-1}\right)$ 1741, 1708, 1216. Anal. calcd for $\mathrm{C}_{10} \mathrm{H}_{15} \mathrm{NO}_{4} \mathrm{~S}:$ C, 48.96; H, 6.16; N, 5.71; Found: C, 48.63; H, 5.77; N, 5.76.

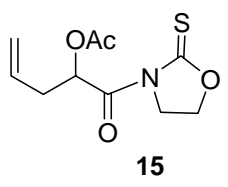

Compound 15 was prepared by method A in 70\% overall yield from the corresponding $\alpha$-hydroxy acid, which was prepared by the method of Wada. ${ }^{5}$

${ }^{1} \mathrm{H}$ NMR $\left(500 \mathrm{MHz}, \mathrm{CDCl}_{3}\right): \delta 6.73(\mathrm{dd}, 1 \mathrm{H}, \mathrm{J}=3.5,9 \mathrm{~Hz}), 5.81-5.90(\mathrm{~m}, 1 \mathrm{H})$, 5.12-5.20 (m, 2H), 4.56-4.61 (m, 2H), 4.26-4.30 (m, 1H), 4.14-4.18 (m, 1H), 2.78-2.84. $(\mathrm{m}, 1 \mathrm{H}), 2.53-2.59(\mathrm{~m}, 1 \mathrm{H}), 2.11(\mathrm{~s}, 3 \mathrm{H}) .{ }^{13} \mathrm{C} \mathrm{NMR}\left(100 \mathrm{MHz}, \mathrm{CDCl}_{3}\right): \delta$ 185.0, 171.1, 170.8, 132.1, 118.9, 71.9, 67.3, 47.3, 35.0, 20.6. $\mathrm{mp}=70-71$. IR $\left(\mathrm{cm}^{-1}\right)$ 1743, 1709, 1219. Anal. calcd for $\mathrm{C}_{10} \mathrm{H}_{13} \mathrm{NO}_{4} \mathrm{~S}$ : C, 49.37; H, 5.39; N, 5.76; Found: C, 49.03; H, 


\section{Typical Procedure for the Kinetic Resolutions}

All entries in Table 2 were determined by averaging the conversion and enantiomeric excess of two runs, then calculating the s-factor using the average data. As such, the data for each individual run will be different from the average data provided in the table.

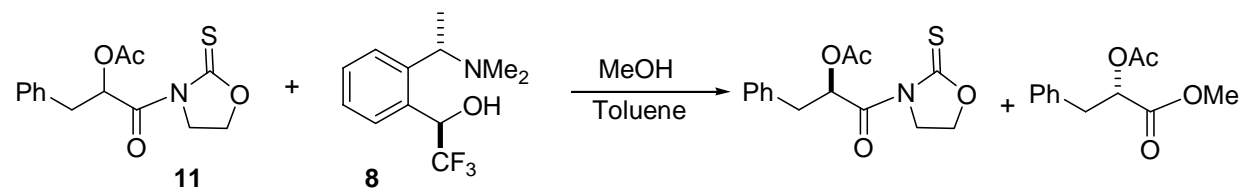

Typical Procedure, Table 1, Entry 2: A mixture of thioimide 11 (121.2 mg, $0.413 \mathrm{mmol})$ and anthracene $(0.0043 \mathrm{mmol}$, internal standard $)$ was dissolved in toluene $(2 \mathrm{ml})$, and cooled to $0{ }^{\circ} \mathrm{C}$. Catalyst $8(10.22 \mathrm{mg}, 0.0413 \mathrm{mmol})$ was then added as a solution in toluene and the reaction stirred for $5 \mathrm{~min}$. Methanol $(500 \mu \mathrm{L}, 20.7 \mathrm{mmol})$ was then added, and the progress of the reaction was monitored by HPLC analysis as follows: $2 \mu \mathrm{L}$ Aliquots of the reaction were taken and diluted with $200 \mu \mathrm{l}$ of a 1:1 hexanes ethanol solution, $50 \mu$ of which were directly injected onto a chiralcel OD column $(250 \mathrm{x}$ $4.6 \mathrm{~mm}$ ). Elution with 7:1 hexanes - isopropanol provided separation of all the reaction components, and the amount of starting material remaining was measured against the internal standard. The reaction was allowed to proceed for 55 hours, then concentrated at reduced pressure to approximately $10 \%$ of its original volume. An aliquot was taken to determine conversion, which was found to be $58.5 \%$. The residue was placed directly on a silica gel flash chromatography column and purified (4:1 hexanes - ethyl acetate) to provide recovered 11 (48.9 $\mathrm{mg}$, 97\% of theory based on $58.5 \%$ conversion). The enantiomeric excess of this material was determined to be $99.3 \%$ using the method described above (flow rate $=1.5 \mathrm{~mL} / \mathrm{min}$, retention times $=55 \mathrm{~min}, 110 \mathrm{~min}, 7: 1$ hexanes-isopropanol). An ee of $99.3 \%$ at $58.5 \%$ conversion corresponds to an $s$ value of 31 .

A duplicate run provided recovered starting material of $99.5 \%$ ee at $59 \%$ conversion which corresponds to an $s$ value of $31 .[\alpha]_{\mathrm{D}}=+64.6(\mathrm{c}=2.4$, EtOAc $)$.

Table 1, Entry 3: The typical procedure was followed using $31 \mathrm{mg}(0.106$ mmol) of compound $11,1.3 \mathrm{mg}(0.00528 \mathrm{mmol}, 5 \%$ catalyst loading $)$ of catalyst $\mathbf{8}$, and $129 \mu \mathrm{L}(3.17 \mathrm{mmol})$ of $\mathrm{MeOH}$. The reaction was stirred for 120 hours $(58.9 \%$ conversion), and purified by flash chromatography on neutral silica to provided recovered $11(12.2 \mathrm{mg}, 96 \%$ of theory) of $99.6 \%$ ee (flow rate $=1.5 \mathrm{~mL} / \mathrm{min}$, retention times $=55$ $\min , 110 \mathrm{~min}, 7: 1$ hexanes-isopropanol). An ee of $99.6 \%$ at $58.9 \%$ conversion corresponds to an $s$ value of 32 . 


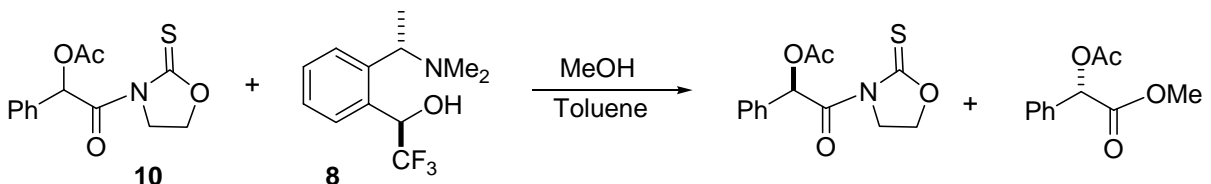

Table 1, Entry 1: The typical procedure was followed (except that the overall concentration was $0.08 \mathrm{M}$ due to the insolubility of the substrate at higher concentration) using $121.3 \mathrm{mg}(0.434 \mathrm{mmol})$ of compound 10,10.7 $\mathrm{mg}(0.0434 \mathrm{mmol})$ of catalyst 8 , and $527 \mu \mathrm{L}(21.7 \mathrm{mmol})$ of $\mathrm{MeOH}$. The reaction was stirred for 67 hours $(58.3 \%$ conversion), and flash chromatography on neutral silica provided recovered $\mathbf{1 0}(45.8 \mathrm{mg}$, $91 \%$ of theory) of $95 \%$ ee (flow rate $=1.5 \mathrm{~mL} / \mathrm{min}$, retention times $=26 \mathrm{~min}, 75 \mathrm{~min}$, 2:1 hexanes-isopropanol). $[\alpha]_{\mathrm{D}}=-53(\mathrm{c}=1.57$, EtOAc). An ee of $95 \%$ at $58.3 \%$ conversion corresponds to an $s$ value of 19.

A duplicate run provided recovered $\mathbf{1 0}$ in $92 \%$ ee at $58.6 \%$ conversion which corresponds to an $s$ value of 15 .

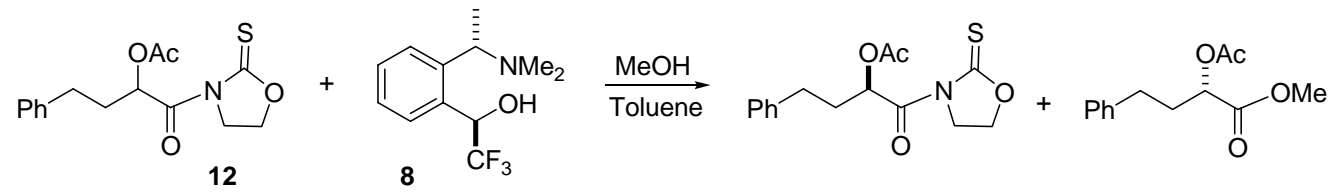

Table 1, Entry 4: The typical procedure was followed using $121.7 \mathrm{mg}(0.396$ mmol) of compound 12, $9.8 \mathrm{mg}(0.0396 \mathrm{mmol})$ of catalyst $\mathbf{8}$, and $481 \mu \mathrm{L}(19.8 \mathrm{mmol})$ of $\mathrm{MeOH}$. The reaction was stirred for 93 hours (58.6\% conversion), and flash chromatography provided $49.8 \mathrm{mg}$ (99\% of theory) of recovered $\mathbf{1 2}$ of $96.3 \%$ ee (flow rate $=1.5 \mathrm{~mL} / \mathrm{min}$, retention times $=26 \mathrm{~min}, 37 \mathrm{~min}, 2: 1$ hexanes-isopropanol $),[\alpha]_{\mathrm{D}}=$ $+102.8(\mathrm{c}=2.1$, EtOAc). An ee of $96.3 \%$ at $58.6 \%$ conversion corresponds to an $s$ value of 20.2 .

A duplicate run provided recovered $\mathbf{1 2}$ in $96 \%$ ee at $58.2 \%$ conversion which corresponds to an $s$ value of 21 .

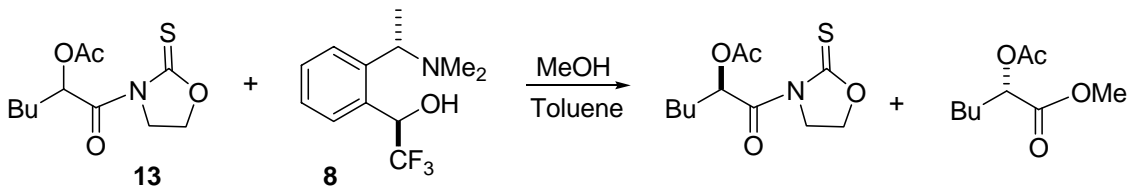

Table 1, Entry 5: The typical procedure was followed using $84.0 \mathrm{mg}(0.324$ mmol) of compound $13,8.01 \mathrm{mg}(0.0324 \mathrm{mmol})$ of catalyst $\mathbf{8}$, and $393 \mu \mathrm{L}(16.2 \mathrm{mmol})$ of $\mathrm{MeOH}$. The reaction was stirred for 116 hours $(56.3 \%$ conversion), and flash chromatography provided $35.3 \mathrm{mg}$ (96\% of theory) of recovered 13 of $96.4 \%$ ee (flow rate $=1.5 \mathrm{~mL} / \mathrm{min}$, retention times $=38 \mathrm{~min}, 85 \mathrm{~min}, 4: 1$ hexanes-isopropanol $),[\alpha]_{\mathrm{D}}=$ $+115.8(\mathrm{c}=2.2, \mathrm{EtOAc})$. An ee of $96.4 \%$ at $56.3 \%$ conversion corresponds to an $s$ value of 27.3.

A duplicate run provided recovered 13 in $96.3 \%$ ee at $56.6 \%$ conversion which corresponds to an $s$ value of 25.8 . 


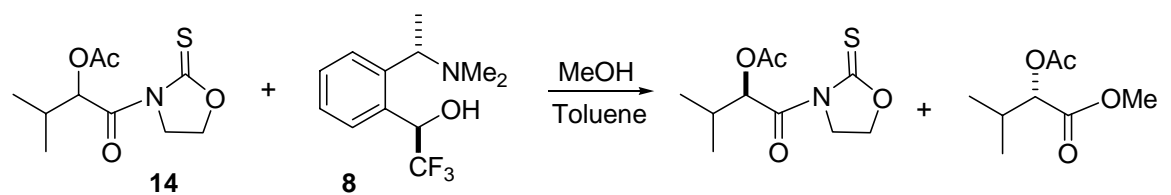

Table 1, Entry 6: The typical procedure was followed, except the reaction was conducted at room temperature using $120.8 \mathrm{mg}(0.492 \mathrm{mmol})$ of the compound $14,12.2$ $\mathrm{mg}(0.0492 \mathrm{mmol})$ of catalyst 8 , and $598 \mu \mathrm{L}(24.6 \mathrm{mmol})$ of $\mathrm{MeOH}$. The reaction was stirred for 7 days (59\% conversion), and flash chromatography provided $49.5 \mathrm{mg}$ (100\% of theory) of recovered 14 of $96.2 \%$ ee (flow rate $=1.5 \mathrm{~mL} / \mathrm{min}$, retention times $=28$ $\min , 100 \mathrm{~min}, 4: 1$ to $3: 2$ hexanes-isopropanol) $[\alpha]_{\mathrm{D}}=+69.8(\mathrm{c}=2.4$, EtOAc). An ee of $96.2 \%$ at $59 \%$ conversion corresponds to an $s$ value of 19.1 .

A duplicate run provided recovered 14 in $95.8 \%$ ee at $57.5 \%$ conversion which corresponds to an $s$ value of 22 .

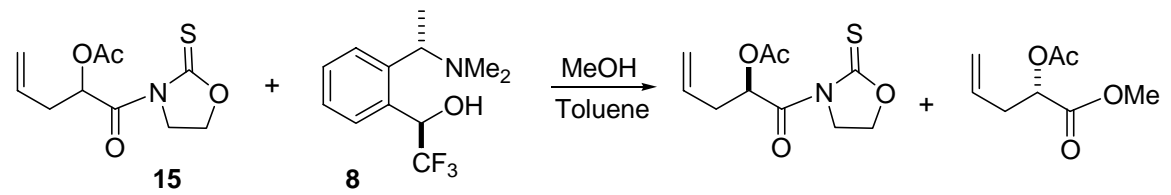

Table 1, Entry 7: The typical procedure was followed, except the reaction was conducted at $-26{ }^{\circ} \mathrm{C}$ using $29.7 \mathrm{mg}(0.122 \mathrm{mmol})$ of compound 15, $3.02 \mathrm{mg}(0.0122$ $\mathrm{mmol})$ of catalyst 8 , and $148 \mu \mathrm{L}(6.10 \mathrm{mmol})$ of $\mathrm{MeOH}$. The reaction was stirred for 7 days (56\% conversion), and flash chromatography on neutral silica provided $13.1 \mathrm{mg}$ ( $98 \%$ of theory) of recovered $\mathbf{1 5}$ in $94.5 \%$ ee (flow rate $=1.5 \mathrm{~mL} / \mathrm{min}$, retention times $=$ $31 \mathrm{~min}, 92 \mathrm{~min}, 7: 1$ hexanes-isopropanol) $[\alpha]_{\mathrm{D}}=+107(\mathrm{c}=1.15$, EtOAc). An ee of $94.5 \%$ at $56 \%$ conversion corresponds to an $s$ value of 24.1 .

A duplicate run provided recovered 15 in $87 \%$ ee at $53.3 \%$ conversion which corresponds to an $s$ value of 20.5 .

\section{Determination of Absolute Configuration}

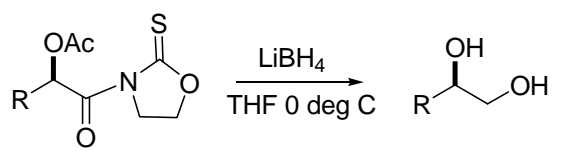

Typical Procedure for the Lithium Borohydride Reduction of Recovered Oxazolidinethione Substrates: To a stirred solution of the recovered starting material $(1.0 \mathrm{mmol})$ in THF $(10 \mathrm{ml})$ at $0^{\circ} \mathrm{C}$, was added $\mathrm{LiBH}_{4}(4.0 \mathrm{mmol})$. The reaction was warmed to room temperature and stirred for 1 hour, and water was then added to quench the reaction. The mixture was diluted with ether, and washed with brine. The organic layer was dried over $\mathrm{MgSO}_{4}$, filtered, and concentrated at reduced pressure. Purification by flash chromatography (1:1 methylene chloride : ethyl acetate) afforded the diol, the optical rotation of which was compared to that reported in the literature. All spectral data were identical to that reported in the literature. The stereochemistry of compounds 10, 11 and 13 was determined in this way. All other compounds were assigned by analogy. Furthermore, in our HPLC analysis, it was always the case that the faster reacting 
oxazolidinethione eluted first.

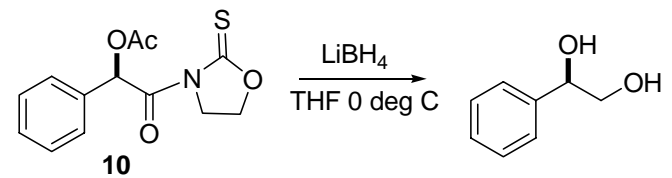

(R)-2-Phenyl-1,2-ethanediol Substrate $\mathbf{1 0}$ was reduced with $\mathrm{LiBH}_{4}$ according to the typical procedure described above, and the diol was purified by flash chromatography (1:1 methylene chloride : ethyl acetate), and the optical rotation was measured. $[\alpha]_{\mathrm{D}}{ }^{28}=-$ $58.0(\mathrm{c}=1.1, \mathrm{EtOH}), \operatorname{lit}^{6}[\alpha]_{\mathrm{D}}=+38.4(\mathrm{c}=4.38 \mathrm{EtOH}, \mathrm{S}-\mathrm{diol})$. This information was used to assign the configuration of substrate $\mathbf{1 0}$ to be $\mathrm{R}$ as shown in the scheme above.

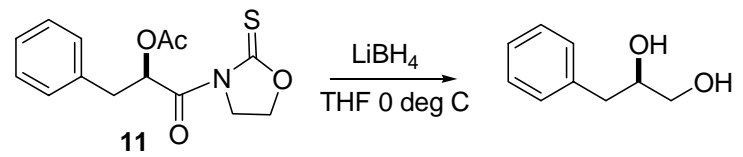

(R)-3-Phenyl-1,2-propanediol Substrate 11 was reduced with $\mathrm{LiBH}_{4}$ according to the typical procedure described above, and the diol was purified by flash chromatography (1:1 methylene chloride : ethyl acetate), and the optical rotation was measured. $[\alpha]_{\mathrm{D}}=+28.6(\mathrm{c}=1.76$, EtOH $)$, Lit. $^{6}[\alpha]_{\mathrm{D}}{ }^{27}=-29.4(\mathrm{c}=1.1$, EtOH, S-diol $)$. This information was used to assign the configuration of recovered $\mathbf{1 1}$ to be $\mathrm{R}$ as shown in the scheme above.

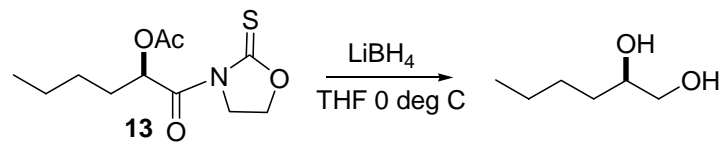

(R)-1,2-Hexanediol Substrate 13 was reduced with $\mathrm{LiBH}_{4}$ according to the typical procedure described above, and the diol was purified by flash chromatography (1:1 methylene chloride : ethyl acetate), and the optical rotation was measured. $[\alpha]_{D}=$ $+14.8(\mathrm{c}=0.76$, EtOH $)$, Lit. ${ }^{6}[\alpha]_{\mathrm{D}}=+15.2(\mathrm{c}=13.14$, EtOH $)$. This information was used to assign the configuration of recovered $\mathbf{1 3}$ to be $\mathrm{R}$ as shown in the scheme above.

X-ray structure of compound 8: The structure of compound $\mathbf{8}$ was determined by X-ray crystallography. A pure sample of this compound was concentrated to a solid at reduced pressure from dichloromethane in a vial, then placed in a $-26{ }^{\circ} \mathrm{C}$ freezer. After a few days, several small crystals had apparently sublimed onto the side of the vial, one of which was collected and deemed suitable for X-ray diffraction. In the crystal structure, two molecules were observed in the unit cell, one of which has an intramolecular H-bond between the $\mathrm{OH}$ and $\mathrm{NMe}_{2}(\mathbf{8 A}$, Figure 1). The other conformer, (8B, Figure 1) is involved in an intermolecular H-bond to an adjacent molecule related by a screw axis, and thereby assembles into chains (not shown). 


\section{Page S10}

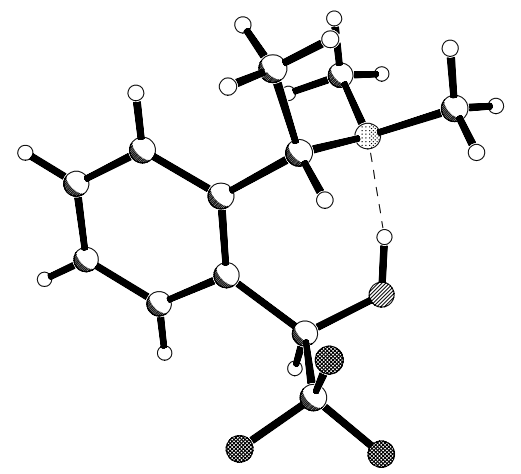

8A

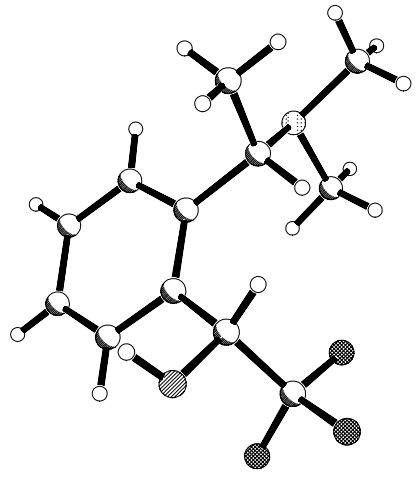

8B

Figure 1. X-ray structure of compound 8. 